\title{
KOMPETENSI HUKUM PEMENUHAN NAFKAH ISTRI PASCA PERCERAIAN
}

\author{
Hasanatul Jannah \\ Penyuluh Agama, lulusan Magister Sosiologi Universitas Gadjah Mada Yogyakarta \\ Mobile Phone: \\ Email:
}

\begin{abstract}
Abstrak
Pemenuban nafkah istri bukan hanya ketika ikatan perkawinan masih terjalin, namun pasca perceraian nafkah istri juga harus dipenubi. Agama sangat jelas mengatur dan menjembatani hal-hal yang berkaitan dengan pemenuban nafkah istri. Problem seputar nafkah istri pasca perceraian sering kali menjadi kasus yang tak. kunjung usai, karena banyak terjadi dari pibak mantan suami lalai memenubi kewajibannya terhadap mantan istrinya, akibatnya pibak istri sering kali dirugikan. Kasus yang sering mencuat ke permukaan masyarakat adalab disebabkan banyaknya istri yang awam bukum diselesaikan begitu saja, sementara bak- baknya diabaikan. Hal tersebut disebabkan karena masih banyak masyarakat yang belum melek bukum, terutama yang berkaitan dengan bukum-bukum agama. Di sisi lain suami masib cenderung menyepelekan kewvajiban karena dianggap persoalan sudah selesai seiring dengan putusan cerai, sehingga banyak yang tak memenubi kewajibannya seperti: memberi nafkah selama iddah, pembagian harta bersama (gono gini), melunasi mahar yang terutang dan memberikan biaya hadhanah kepada anak-anaknya.

Maintenance is not only the right of wife in the bond of marriage but also after the divorce. However, women mostly denied the right of maintenance after the dissolution of marriage. This denial is partly resulted from the women's ignorance of their legal right and partly due to the negligence of the men to carry out their duty of maintenance falsely considering that the duty has ended by the termination of marriage. Maintenance during the waiting period (iddab), distribution of estates (gono gini), giving the unpaid dower, and widow right of retention are among the perplexing issues following the dissolution of marriage. Sanction against the violation of these rulings should be enacted and implemented.
\end{abstract}

\section{Kata Kunci:}

\section{Pendahuluan}

Pernikahan merupakan peristiwa yang agung dalam sejarah kehidupan manusia. Peristiwa tersebut menjadi sakral, karena terjadi penyatuan jenis kelamin antara laki-laki dan perempuan dengan kompensasi sebuah ibadah yang tak ternilai harganya dihadapan Allah SWT dan Rasulnya.
Sebagai sunnatullah, menikah merupakan sebuah upaya membentuk keluarga yang utuh, karena menikah merupakan sebuah jalan untuk membangun masyarakat yang lebih beradab dan terhormat di atas fondasi yang kokoh. Dengan demikian menikah merupakan pijakan utama untuk membentuk keluarga atau batu utama dari susunan bangunan 
masyarakat tersebut. ${ }^{1}$ Substansi sebuah pernikahan adalah kasih sayang, kecintaan, kehormatan, pembelajaran, kerjasama dan sebagainya. Dalam pernikahan seorang suami maupun istri dilatih untuk memiliki mental sportif dari naluri kemanusiaan yang sehat, yang sejalan dengan perasaan, hati dan pikiran.

Menurut Anthony Giddens, ${ }^{2}$ keluarga merupakan institusi dasar masyarakat madani, karena keluarga mempunyai peluang yang sangat signifikan dalam pembentukan masyarakat. Tidak bisa dipungkiri lagi, bahwa setiap manusia mendambakan kehidupan berkeluarga yang harmonis dan sejahtera, sehingga keputusan untuk menikah merupakan sebuah keputusan bulat untuk membangun sebuah bangunan rumah tangga yang utuh, kuat dan kokoh.

Dalam setiap agama terdapat aturan sendiri terhadap keberlangsungan sebuah pernikahan, agama Islam memberikan pedoman kepada manusia sesuai dengan tuntunan fitrah hidupnya yang multidimensional. Seperti fitrah manusia yang bernaluriah seksual dan berketurunan, maka menikah merupakan solusi yang "beradab dan berkehormatan".

Menikah, awalnya merupakan sebuah citacita luhur yang bertujuan untuk membangun sebuah rumah tangga bahagia berdasarkan koridor agama, kemudian terealisasi dibawah legalitas hukum normatif dan hukum agama. Namun pada akhirnya menjadi sebuah persoalan panjang ketika maghligai rumah tangga menemukan kebekuan dari setiap persoalan yang tak kunjung terselesaikan, sehingga indikasinya kondisi rumah tangga menjadi kritis dan berujung pada perceraian. Maka muncul kemudian masalah seputar pemenuhan nafkah istri pasca perceraian yang seringkali terabaikan karena faktor minimnya kesadaran terhadap hukum oleh masingmasing pasangan.

Problem seputar nafkah istri pasca

\footnotetext{
${ }^{1}$ Ali Abd Halim Mahmud, Figh dakwah muslimah, (Jakarta: Robbani Press, 1991) hlm.163

2 Anthony Giddens, Jalan ketiga, pembaharuan demokrasi sosial, (Jakarta: Gramedia, 1998) hlm. 102
}

penceraian sering kali menjadi problem yang paling urgen dalam sengketa rumah tangga. Karena banyak terjadi dari pihak mantan suami lalai bahkan enggan memenuhi kewajibannya terhadap mantan istrinya, akibatnya pihak istri seringkali dirugikan. Kasus yang sering mencuat ke permukaan adalah penelantaran dan penggantungan persoalan, sehingga yang semestinya merupakan hak menjadi terabaikan. Penyebab yang paling mendasar adalah belum tersentuhnya kesadaran hukum pada masing-masing pasangan terutama dari pihak suami, sehingga banyak kasus ditemukan suami lengah memenuhi kewajibannya seperti: memberi nafkah selama iddah, pembagian harta bersama (gono gini), melunasi mahar yang terutang dan memberikan biaya hadhanah kepada anak-anaknya. Begitu pula lemahnya pemahaman istri terhadap hukumhukum agama menjadikannya tidak memiliki kekuatan menawar (bargaining position) terhadap hak yang mestinya didapat.

\section{Membangun Kesadaran Hukum Dalam Perkawinan Dan Pasca Perceraian}

Keluarga terdiri dari sepasang suami istri dan dilengkapi oleh kehadiran anak-anak. Masing-masing memiliki fungsi dan kewajiban yang berbeda-beda, namun tetap dalam satu bingkai yang sama, yakni sama-sama mengusung bahtera rumah tangga. Sebagai unit terkecil dalam struktur masyarakat, keluarga dimulai dari sebuah aqad nikah, bukanlah aqad jual-beli, bukan aqad sewamenyewa apalagi aqad perbudakan, akan tetapi aqad pernikahan adalah suatu ikatan perjanjian yang kuat, dimana di dalamnya terdapat berbagai tatanan yang mengikat seluruh anggota keluarga. Membangun rumah tangga adalah membentuk suatu sistem mekanisme rasional yang menuntut tanggung-jawab atas pemenuhan hak dan kewajiban secara utuh dan seimbang, yang berimplikasi pada keseimbangan, kebahagiaan dan kenormalan dalam perkawinan.

Namun realitanya, sebuah perkawinan banyak menemukan berbagai hambatan, 
problem, gangguan dan godaan lainnya yang mengarah pada disharmonisasi bahkan perceraian, kecuali bagi pasangan yang mampu bertahan dan pandai mencari solusi pada setiap persoalan. Asumsi mendasar para ahli masalah perkawinan (marriage counselors) ada beberapa alasan yang menyebabkan suatu pernikahan tetap bertahan di tengah maraknya perceraian salah satu diantaranya; antara suami dan istri sama-sama menghayati kewajiban masing-masing. Hasil penelitian para ilmuwan, tentang keharmonisan perkawinan diketahui bahwa ada tiga faktor utama yang menentukan kebahagiaan suami istri; pertama, faktor kepribadian, yakni kemampuan mengendalikan diri, optimis, kerjasama, kedua, faktor lingkungan keluarga, yakni tak adanya pertentangan antara anggota keluarga, ketiga, faktor seksual, yakni untuk melangsungkan keturunan secara normal.

Ketidakmampuan mengelola perkawinan memunculkan keretakan dalam rumah tangga yang berakibat perceraian. Sebagai bagian dari problem perkawinan, perceraian akan senantiasa muncul dalam ranah kehidupan manusia sebagai konsekwensi logis dari sebuah kegagalan perkawinan. Perceraian merupakan jalan terakhir yang harus ditempuh oleh suamiistri bila tidak mampu mempertahankan perkawinan, akibat dari ketidakmampuan salah satu pihak menegakkan haknya dan menjalankan kewajibannya, ${ }^{3}$ disinyalir penyebab sebuah perkawinan tidak awet karena beberapa faktor; pertama, tidak adanya niat yang kokoh untuk mempertahankan perkawinan, kedua, tidak memiliki tujuan hidup berumah-tangga yang jelas, ketiga, hubungan suami istri tidak harmonis, keempat, tidak menempatkan peranan agama sebagai penunjang awetnya perkawinan dan; kelima, terjadinya sengketa dalam rumah tangga.

Dalam hal membangun kehidupan rumahtangga yang harmonis, pemahaman terhadap hukum-hukum agama menjadi mutlak diperlukan, sehingga suami-istri mengetahui dan berupaya memenuhi hak dan kewajiban

${ }^{3}$ Hanna Djumhana B, Integrasi Psikologi Dengan Islam,(Yogyakarta: pustaka pelajar, 1995), hlm. 204 masing-masing. Kesadaran hukum tersebut perlu disentuh untuk sebuah keberlangsungan rumah tangga. Banyaknya perselisihan dan perpecahan dalam rumah-tangga disebabkan karena dangkalnya pemahaman nilai-nilai agama dan kurangnya kematangan emosi dari pihak suami dan istri. Terjadinya perceraian diakibatkan pula memburuknya manajemen rumah-tangga dan tidak adanya penghargaan kepada pasangannya. Apapun dasarnya, perceraian merupakan suatu tindakan yang dihalalkan namun dibenci oleh Allah SWT. Dan pada gilirannya penceraian akan berakibat buruk dalam relasi suami istri terutama bila memiliki keturunan, karena sering kali yang muncul pasca penceraian adalah persoalan nafkah istri dan anak, harta bersama (gono gini) dan pengasuhan anak.

Seperti dalam kasus Pasca peceraian yang banyak terjadi di tengah-tengah masyarakat, suami tidak bisa menjalankan putusan pengadilan atau menjalankan putusan pengadilan tetapijumlah nafkah yang diberikan kepada bekas istri tidak sesuai dengan putusan pengadilan, bahkan cenderung lebih kecil, dan yang lebih memprihatinkan lagi sang mantan istri sama sekali tidak mengetahuinya kalau dirinya masih memiliki hak yang harus diperjuangkan. Akibat ketidaktahuan istri mengenai hak-haknya, menjadi penyebab yang rentan bagi istri untuk menerima kerugian dalam persoalan nafkah pasca perceraian.

Sebenarnya hak-hak istri yang dicerai sudah diatur dalam undang-undang perkawinan dan Kompilasi Hukum Islam, namun masih banyak istri tidak mengetahui sehingga mantan suami dengan mudah menyepelekan kewajibannya memberikan hak yang mesti diterima istrinya. Persoalan hak dan kewajiban suami istri bila terjadi perceraian sangat terkait dengan kesadaran hukum kedua belah pihak, terutama masyarakat yang masih memiliki pendidikan minim, karena tujuan penegakan hukum adalah untuk menciptakan masyarakat yang sadar, bertanggung jawab terhadap hak dan kewajiban mereka. Untuk menumbuhkan kesadaran hukum, berbagai 
pihak punya kompenten artinya misi tersebut bukan hanya milik lembaga hukum saja, namun semua lembaga pemerintahan maupun swasta dipandang perlu untuk ikut andil menyosialisasikannya.

\section{Menimbang Ukuran Nafkah Istri Dalam Ikatan Perkawinan Dan Pasca Perceraian}

\section{Nafkah Istri dalam Ikatan Perkawinan.}

Nafkah untuk istri bermacam-macam sesuai dengan kebutuhan, seperti makanan, tempat tinggal, pelayanan (perhatian), pakaian, dan lain-lain. Nafkah istri merupakan kewajiban suami yang harus diberikan kepada istri dan disesuaikan dengan kemampuan suami, ${ }^{4}$ firman Allah SWT dalam surat AtThalaq: 7 :

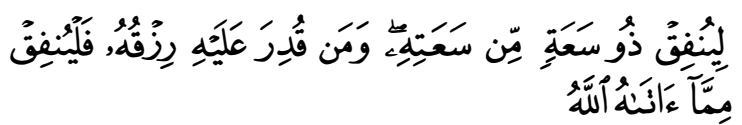

Artinya: "bendaknya orang yang mampu memberi nafkah menurut kemampuannya dan orang yang disempitkan rizqinya hendaklab memberi nafkah dari barta yang diberikan Allab SWT kepadanya".

Pasal 80 KHI menyatakan, bahwa suami mempunyai kewajiban untuk memberikan nafkah, kiswah dan tempat kediaman bagi istri, biaya rumah tangga, biaya perawatan dan biaya pengobatan bagi istri dan anakanak, biaya pendidikan bagi anak-anak.

Sebagai sebuah bentuk kewajiban bagi suami terhadap istri, maka nafkah istri menjadi sebuah keniscayaan yang harus ditunaikan oleh suami karena faktor keterikatan seorang istri terhadap suami dan tertahan sebagai miliknya, karena suami telah menikmati istrinya. ${ }^{5}$

Dalam perundang-undangan Indonesia tidak mempunyai sub khusus yang membahas masalah nafkah dalam rumah tangga. Namun hadist nabi menekankan tentang urgennya pemberian nafkah, sebagaimana Imam

\footnotetext{
${ }^{4}$ Anshori Umar, Fiqh Wanita, (Semarang: Asy'syifa', tt), hlm.463

${ }^{5}$ Sayyid Sabiq, Fiqh Sunnah 7, (Bandung, Al-Ma'ari, 1981), hlm. 80.
}

Muslim meriwayatkan dari Abu Hurairahr r.a. bahwa Rasulullah bersabda:

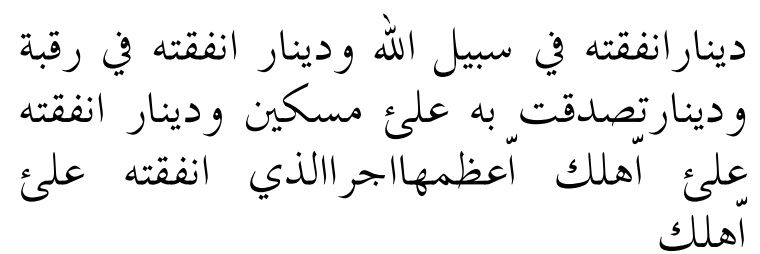

Artinya: 'Satu dinar yang engkau belanjakan di jalan Allah, dan satu dinar yang engkau belanjakan untuk memerdekakan budak, dan satu dinar yang engkau sedekabkan untuk orang miskin, serta satu dinaryang engkau belanjakan untuk keluargamu, yang lebih besar pabalanya adalah satu dinar untuk. keluargamu. ${ }^{6}$

Nafkah diukur menurut kebutuhan istri dengan ukuran yang makruf, yaitu ukuran yang baik bagi setiap pihak dengan mengingat kebiasaan yang berlaku, karena itu jumlah nafkah berbeda menurut zaman, tempat dan kondisi riil masyarakat. Sebagaimana dijelaskan dalam surat Al-Baqorah:233:

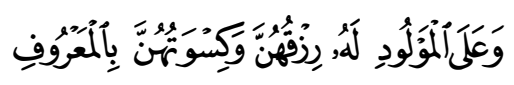

Artinya: Dan kewajiban ayah memberi makan dan pakaian kepada ibu dan anak dengan cara yang makruf.

Konsep tentang nikah menurut ulama fiqh antara lain: ${ }^{7}$ Mazhab Maliki memandang nafkah keluarga sebagai sebuah kewajiban bagi suami setelah menunaikan mahar, seperti tempat tinggal dan keperluan hidup rumah tangga, Mazhab Hanafi memandang bahwa mencukupi nafkah istri merupakan kewajiban kedua dari suami setelah mahar. Adapun ukuran nafkah yang harus ditunaikan oleh suami adalah disesuaikan dengan kebiasaan tempat tinggal mereka. Mąhab Syafii memandang bahwa nafkah merupakan hak yang wajib diterima oleh istri dari suami, cakupan nafkah yang wajib ditunaikan oleh suami adalah biaya susuan, sandang, pangan, tempat tinggal dan kebutuhan seksual. Namun kadar nafkah yang harus diberikan

\footnotetext{
${ }^{6}$ Abd. Halim Mahmud, Figh Dakwah Muslimah, (Jakarta: Robbani Press, 1991), hlm. 182

${ }^{7}$ Khairuddin Nasution, Islam Tentang Relasi Suami \& Istri (Hukum Perkawinan), (Yogya: Akademia \& Tazzafa, 2004), hlm. 175
} 
suami kepada istri adalah disesuaikan dengan kemampuan dan kepantasan dimana mereka tinggal. Mą̧ab Hambali memandang bahwa memenuhi nafkah istri hukumnya wajib bagi suami. Nafkah yang wajib dipenuhi suami adalah semua kebutuhan untuk kelangsungan hidup berumah tangga.

Dari berbagai pandangan para ulama' mazdhab tersebut, jelas sekali bahwa seorang suami wajib memberi nafkah kepada istrinya sesuai dengan kemampuannya. Nafkah tersebut beraneka ragam sesuai dengan kebutuhan para istri, seperti makanan yang sesuai dengan kondisi daerah masing-masing, pakaian yang layak, dan lain-lain. Namun apabila suami dalam himpitan ekonomi yang sulit, maka seorang suami diwajibkan memberikan nafkah kepada istri disesuaikan dengan kemampuan suami.

\section{Nafkah Istri Pasca Perceraian}

Dalam Kompilasi Hukum Islam dijelaskan, bilamana perkawinan putus karena thalak, maka bekas suami wajib:

Memberikan mut'ah yang layak kepada bekas istrinya baik berupa uang atau denda, kecuali bekas istri tersebut qobla dubul.

Memberi nafkah. Maskan dan kiswah kepada bekas istri selama dalam iddah, kecuali bekas istri telah dijatuhi thalak ba'in atau nusyuz dalam keadaan tidak hamil

Melunasi mahar yang masih terhutang seluruhnya dan separuh umur 21 tahun (bab. XVI, Pasal. 149).

Imam Malik memandang nafkah pasca perceraian menjadi tidak wajib bila terjadi thalak ba'in kecuali istri sedang hamil, sedangkan untuk thalak raj'i wajib nafkah (semua jenis, hamil atau tidak) sampai habis masa iddah. Menurut Imam Syafi'i memberi nafkah pasca perceraian sampai masa iddah untuk thalak raj'i, sedangkan thalak ba'in tidak wajib dengan alasan sesudah thalak ada hubungan seksual (istimta'). ${ }^{8}$

${ }^{8}$ Khairuddin Nasution, Islam tentang relasi suami \& istri (bukum perkawinan), (Yogya: Akademia \& tazzafa, 2004), hlm. 181.
Menurut Anshori, ${ }^{9}$ nafkah sudah menjadi ketetapan Allah SWT atas para suami, dimana seorang suami memberi nafkah kepada istriistrinya meskipun telah bercerai dan masih dalam masa iddah, sebagaimana firman Allah SWT dalam surat Al-Baqarah: 241:

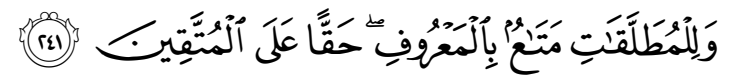

Artinya: "kepada wanita-wanita yang diceraikean (bendaknya diberikan oleh suaminya) mut'ah menurut yang makruf, sebagai suatu kewajiban bagi orang-orang yang bertaqwa."

Kewajiban memberi nafkah tersebut tetap berlaku sampai dengan terjadinya perceraian antara suami-istri sesudah jatuhnya talak, dengan harapan dapat mengembalikan hati yang marah menjadi tenang kembali.

Sebagian fuqoha ada yang berpendapat, bahwa mut'ah itu wajib diberikan kepada istri yang telah ditalak apabila suami telah sempat mencampurinya, baik maharnya telah ditentukan ataupun belum. Juga kepada istri yang ditalak sebelum sempat dicampuri apabila maharnya belum ditentukan. Hal tersebut yang mewajibkan suami memberi mut'ah kepada istri yang baru dicerainya. Sedangkan wanita yang dicerai sebelum dicampuri sedang maharnya telah ditentukan, maka ia masih berhak menerima separo mahar. Dengan demikian ia tidak perlu diberi mut'ah lagi. Sebagaimana firman Allah SWT dalam surat Al-Baqorah: 237:

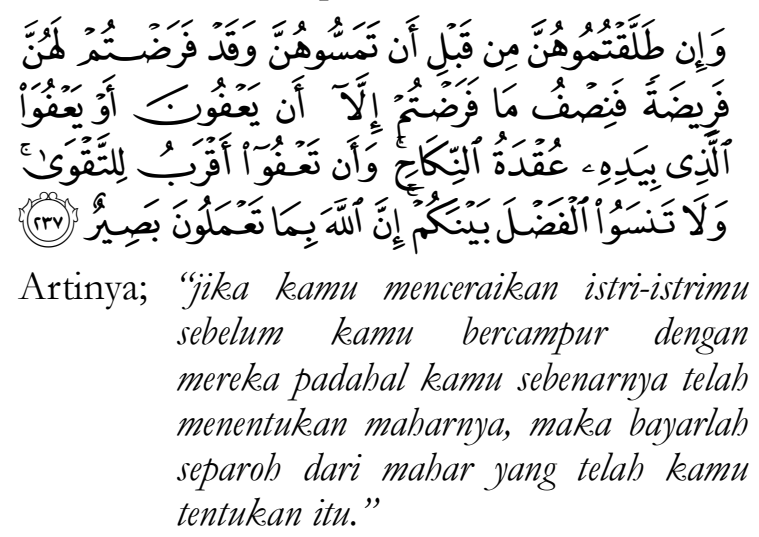

Sebagian ulama berpendapat, bahwa ketentuan (nash) diatas keumumannya

\footnotetext{
${ }^{9}$ Anshori Umar, Fiqh Wanita, (Semarang: Asy'syifa', tt), hlm.460)
} 
mencakup wanita manapun yang diceraikan, dengan ketentuan sampai yang diceraikan sebelum campur sekalipun, juga masih berhak menerima separo mahar, mut'ah itu tetap wajib diberikan kepadanya, disamping separo mahar yang telah ada ketentuannya.

Mut'ah yang wajib diberikan kepada wanita yang diceraikan sesudah campur, merupakan ijmak, sebagimana dijelaskan dalam surat AlBaqarah:241, sebagai berikut:

Artinya: "kepada wanita-wanita yang diceraikan (bendaklah diberikan oleh suaminya) mut'ab menurut yang makruf"

Sedangkan wanita yang diceraikan sebelum campur, sementara maharnya belum ditentukan, maka mereka menerima mut'ah, berdasarkan surat Al-Baqorah:236:

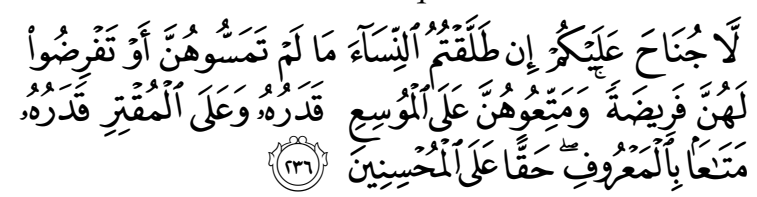

Artinya: 'tidak ada sesuatupun (mahar) atas kamu, jika kamu menceraikan istriistrimu sebelum kamu bercampur dengan mereka dan sebelum kamu menentukan maharnya, dan hendaklah kamu berikan suatu mut'ah (pemberian) kepada mereka. Orang yang mampu menurut kemampuannya dan orang yang miskin menurut kemampuannya (pula) yaitu pemberian menurut yang patut. Yang demikian itu merupakan ketentuan bagi orang-orang yang berbuat kebajikan.

Adapun perempuan yang dalam masa iddah raji atau iddah hamil berhak juga mendapatkan nafkah, sebagaimana firman Allah SWT dalam surat Ath-Thalaq: 6 sebagai berikut:

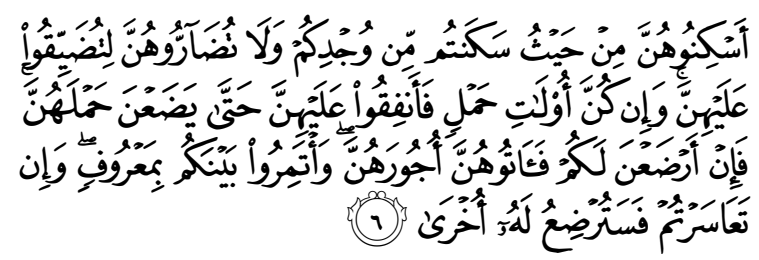

Artinya: "Tempatkanlah mereka (para istri) dimana kamu bertempat tinggal menurut kemampuanmu'.

Menurut Sayyid Sabiq dalam talak bain, para ahli fiqh berbeda pendapat tentang hak nafkahnya jika tidak dalam keadaan hamil, ${ }^{10}$ dimana dalam penjabarannya ada 3 pendapat:

a. Berhak mendapatkan rumah tetapi tidak berhak mendapatkan nafkah. Demikian pendapat Malik bin Syafi'i, alasan dari pendapat tersebut berdasarkan firman Allah dalam surat At-Thalaq: 6 yang artinya: "tempatkanlah mereka (para istri) dimana kamu tinggal menurut kemampuanmu."

b. Berhak mendapatkan nafkah dan rumah. Karena secara hukum memberikan tempat tinggal maka dengan sendirinya wajib memberikan nafkah, karena adanya kewajiban memberi tempat tinggal dalam talak perempuan hamil.

c. Tidak berhak nafkah dan tempat tinggal, dengan alasan tempat tinggal dan nafkah hanyalah hak bagi perempuan yang suaminya ada hak rujuk.

Pada hakekatnya, Allah SWT menjunjung tinggi prinsip kemanusiaan, hal tersebut terbukti dalam memberikan ukuran mut'ah sangat elegan, dengan memberikan ketentuan yang sangat bijaksana, agar pemberian mut'ah diberikan dengan kadar yang patut (makruf) sesuai kemampuan suami.

\section{Mencari Titik Temu Upaya Pemenuhan Nafkah Istri Pasca Perceraian}

Salah satu upaya yang perlu dilakukan terhadap pemenuhan nafkah istri pasca perceraian, adalah adanya dukungan dari berbagai pihak yang terkait, terutama dari pihak suami-istri yang bersengketa. Pihak yang terkait disini adalah Pengadilan Agama yang memiliki kekuatan yuridis formal, Kementerian agama, Badan Penasehatan Perkawinan dan lain-lain.

Kesadaran terhadap hak dan kewajiban suami dan istri pasca perceraian perlu ditingkatkan. Meskipunmasihbelum signifikan bila dibandingkan dengan konsep keagamaan yang cukup mengakar dalam kehidupan masyarakat. Kesadaran dan pemahaman dalam penyelesaian perkara pasca perceraian

\footnotetext{
${ }^{10}$ Sayyid Sabiq, Fiqh Sunnah 7 (Bandung: Al-Ma'arif, 1981), hlm. 98
} 
terutama dalam pemenuhan nafkah istri pasca perceraian sudah semestinya menjadi kesadaran dan permahaman dalam bentuk kongkrit sebagai hasil dari keputusan produk hukum yang produktif dimana antara hak dan kewajiban suami istri pasca perceraian benarbenar dijalankan dan dimaknai sesuai dengan yang tersirat dalam Al-Qur" an dan Hadist.

Hal yang harus dibangun dalam faktor psikologis dari dampak perceraian, adalah memulai menumbuhkan kematangan emosional pasangan suami-istri yang berperkara untuk mencari jalan yang terbaik dan damai tanpa mengedepankan emosi dalam mencapai kesepakatan-kesepakatan dan kesanggupan masing-masing untuk menunaikan tanggung-jawab berdasarkan hak dan kewajiban sehingga tidak ada yang dirugikan pasca perceraian. Karena elemen yang paling mendasar dapat dikatakan berangkat dari disharmonisasinya bahtera rumah tangga suami-istri tersebut, sehingga rentan terhadap benturan yang bersifat emosianal. Seperti sikap amarah dan dendam akibat terjadi perceraian pasangan suami istri, akan membawa hasil yang kontra produktif terhadap keputusan hukum, akhirnya kesepakatan-kesepakatan yang menyakut hak dan kewajiban pasca perceraian tidak akan berjalan sesuai dengan perjanjian antara pasangan suami-istri yang bercerai. Karena factor emosional, seorang suami dapat menghianati perjanjian yang telah disepakati terutama yang menyangkut pemenuhan nafkah istri paska perceraian.

Kekuatan yang paling urgen adalah faktor pendidikan, terutama dalam pemahaman pendidikan keagamaan. sebagian besar dari masyarakat belum sepenuhnya memiliki pemahaman yang menyeluruh terhadap hak dan kewajiban pemenuhan nafkah istri terutama pasca perceraian. Hal ini dapat dilihat dari beberapa kasus perceraian yang terjadi, dimana pasangan suami-istri kurang siap secara keilmuan saat dihadapkan pada masalah hak dan kewajiban pasca perceraian, terutama lagi pada pemenuhan nafkah istri.
Faktor budaya dianggap berpengaruh terhadap paradigma feodalisme dalam mesyarakat yang membuat kaum istri hanya menjadi sub-ordinat sehingga tidak memiliki kekuatan untuk menuntut hakhaknya apabila terjadi perceraian walaupun Pengadilan Agama telah memutuskan bahwa mantan suami diharuskan memenuhi nafkah kepada istri pasca perceraian. Sebagai contoh dari pengamatan terhadap beberapa kasus perceraian yang terjadi di Pengadilan Agama adalah terkesan seringkali seorang istri yang telah bercerai dengan suaminya tidak sedemikian aktif memperjuangkan hakhaknya sebagaimana yang telah dimaktubkan dalam undang-undang karena telah terbukanya peluang sikap superioritas yang sedemikian kental dalam masyarakat feodal.

Menurut hukum Agama (Al Qur'an), dalam harta gono-gini tidak ada peraturanperaturan mengenai harta bersama seperti yang diatur oleh hukum perdata, dengan demikian Al-Qur'an tidak memerintahkan dan tidak pula melarang supaya harta gonogoni dalam perkawinan dipisahkan atau dipersatukan, namun dalam Islam ada kaidah fiqiyyah yaitu: suatu yang tidak dilarang boleh dikerjakan. Dalam hal ini ada kebiasaan yang dipandang baik oleh orang-orang Islam dapat ditetapkan sebagai hukum, asal tidak bertentangan dengan prinsip hukum Islam.

Demikian juga yang mesti dilakukan sebagai bentuk upaya dari hakim dalam persidangan yaitu sebelum dimulai pemeriksaan perkara, maka hakim diwajibkan mengusahakan perdamaian antara pihak-pihak yang berperkara. Jika perdamaian yang diusahakan oleh hakim tersebut berhasil, maka dibuatlah akta perdamaian. Karena perdamaian adalah berkaitan dengan hukum kebendaan, maka akta perdamaian tersebut mempunyai kekuatan untuk dimintakan eksekusi apabila salah satu pihak tidak mentaati isi perdamaian yang telah disepakati. Sebagaimana termaktub dalam pasal 41 UU No. 1 Tahun 1974, sebagai berikut:

- Baik Ibu atau Bapak berkewajiban 
memelihara dan mendidik anak-anaknya semata-mata berdasarkan kepentingan anak, bilamana ada perselisihan mengenai penguasaan anak-anak, maka pengadilan memberi keputusannya.

- Bapak yang bertanggung-jawab atas semua biaya pemeliharaan dan pendidikan yang diperlukan anak, bilamana Bapak dalam kenyataanya tidak dapat memberi kewajiban tersebut, maka Pengadilan memberi keputusannya.

- Pengadilan dapat mewajibkan kepada bekas suami untuk memberikan biaya penghidupan dan atau menentukan suatu kewajiban bagi bekas istri.

Dalam Kompilasi Hukum Islam pasal 156 juga disebutkan sebagai berikut :

Mut'ah wajib diberikan oleh bekas suami dengan syarat: Belum ditetapkan mahar oleh istri ba'da al-dukhul dan Perceraian terjadi atas kehendak suami.

Dalam pasal 160 juga disebutkan bahwa besarnya Mut'ah disesuaikan dengan kepatutan dan kemampuan suami. Persoalan nafkah istri pasca perceraian, merupakan persoalan yang paling urgen diantara berbagai persoalan kehidupan berkeluarga. Seorang suami tetap wajib memberikan nafkah pada bekas istrinya. Hal tersebut berlaku kepada perempuan yang dalam iddah hamil berdasarkan firman Allah SWT dalam surat At-Thalaq 16:

Artinya:" Tempatkanlah mereka (para istri) dimana kamu bertempat tinggal menurut kemampuan."

Kemudian firman Allah tentang nafkah perempuan hamil yang dicerai suaminya :

Artinya:" Dan jika mereka (istri-istri yang sudah ditalak) itu perempuan-perempuan yang sedang hamil, maka berikanlah kepada mereka nafkabnya sampai mereka bersalin."

Berdasarkan ayat tersebut diatas, dan UU yang berlaku dalam Kompilasi Hukum Islam menegaskan, bahwa, persoalan nafkah istri pasca perceraian merupakan persoalan semua pihak, terutama yang berkompeten dalam hukum. Dalam hal ini Pengadilan Agama yang secara yuridis formal sebagai salah satu pelaksana kekuasaan bagi rakyat pencari keadilan yang beragama Islam mengenai perkara perdata.

Dalam wilayah hukum Peradilan Agama , didapati bahwa dalam pemenuhan nafkah istri pasca perceraian telah menggunakan prosedur standar atau umum seperti memberikan penjelasan-penjelasan tentang segala sesuatu yang berkaitan dengan pasca terjadinya perceraian antara suami dan istri, dimana penjelasan tersebut mengacu pada Undang-undang dan Peraturan Perundangan yang berlaku. Wujud dari penjelasan tersebut diantaranya menyangkut garis besar tentang hak dan kewajiban suami-istri paska perceraian.

Adanya ketetapan hukum yang pasti apabila jatuh keputusan Pengadilan Agama atas perceraian antara suami-istri, dimana ketetapan hukum tersebut mengacu pada asas manfaat dan kebaikan sebagai solusi terbaik terhadap permasalahan yang terjadi pada keluarga muslim. Ketetapan tersebut dengan jelas termaktup dalam peraturan perundangan. Misalnya: dalam Kompilasi Hukum Islam di Indonesia.

Bila melihat implikasi dari putusan Pengadilan Agama terhadap kasus perceraian pasangan suami-istri yang terjadi di wilayah hukum, dimana keputusan hukum tersebut bersifat " kepututusan tertulis ", dan tidak mempunyai konskwensi apapun apabila terjadi pengingkaran terhadap keputusan yang berangkat dari kesepakatan suami-istri yang berperkara, maka perlu mekanisme yang jelas dan tegas dari Pengadilan Agama untuk mengamankan dan mengawal keputusan hukum tersebut. Bisa jadi menembuh beberapa mekanisme seperti: Sangsi hukum yang jelas apabila seorang suami mengingkari kesepakatan pemenuhan nafkah istri pasca perceraian, dan Kontrol serta pengawasan yang sistematis agar pelaksanaan keputusan hukum pemenuhan nafkah istri pasca perceraian benar-benar berjalan sesuai dengan keputusan hukum yang telah ditetapkan. Kontrol dan 
pengawasan tersebut dapat berupa lembaga management keuangan yang mengatur masalah pemenuhan nafkah istri pasca perceraian, sehingga suami yang menceraikan istrinya benar-benar menjalankan kewajibanya memberi nafkah pada istri yang dicerainya.

Perlunya intensitas dan keterbukaan dari berbagai kalangan yang berkaitan secara langsung terhadap terbentuknya sebuah keluarga dengan cara memberi penyuluhanpenyuluhan yang sedetai-detailnya agar pasangan suam-istri paham betul terhadap hak dan kewajiban sebagai suami-istri. Terkait hal ini meliputi ulama, tokoh masyarakat, Pengadilan Agama, lembaga pendidikan yang terkoordinasikan secara sisitematis, sehingga apabila terjadi hal-hal yang tidak diinginkan oleh berbagai pihak, misalnya terjadinya perceraian, maka tidak ada yang dirugikan baik secara Psikis ataupun non psikis pasca perceraian suami .

Sosialisasi secara komperhensif terhadap undang-undang dan peraturan perundangan yang menyangkut masalah pernikahan dan perceraian kepada masyarakat sangat penting diupayakan, sehingga menjadi pemahaman yang utuh dan menyeluruh bisa termanifestasikan dalam sendi kehidupan. Sehingga segala aspek hak dan kewajiban menjadi pengertian mendalam dari para suami istri. Termasuk didalamnya yang menyangkut kewajiban suami dalam memenuhi nafkah kepada istri pasca perceraian.

\section{Penutup}

Pemenuhan nafkaf istri pasca perceraian secara tegas didasarkan pada Al-Qur'an dan Hadits, Undang-undang Perkawinan dan peraturan perundangan yang termaktub dalam kompilasi hukum Islam dan Undangundang Republik Indonesia Nomor 7 Tahun 1989 Tentang Peradilan Agama.

Diperlukan pemahaman dan kesadaran yang utuh pada pasangan terutama bila terjadi perkawinan dan perceraian. Apabila perceraian terjadi, mantan suami mengetahui tentang kewajibanya terhadap pemenuhan nafkah pada istri pasca perceraian, dengan keputusan hukum tertulis sesuai dengan kesepakatan suami istri yang berperkara. Terutama untuk Kondisi masyarakat pedalaman rata-rata suami istri yang berperkara dan jatuh putusan perceraian, masih banyak yang memiliki tingkat pendidikan rendah.

\section{Daftar Pustaka}

Abd. Halim Mahmud, Fiqh Dakwah Muslimah, (Jakarta: Robbani Press, 1991).

Ali Abd Halim Mahmud, Fiqh dakwah muslimah, (Jakarta: Robbani Press. (Semarang: Asy'syifa', tt).

Anshori Umar, Fiqh Wanita, Sayyid Sabiq, Fiqh Sunnah 7, (Bandung, Al-Ma'arif, 1981).

Anthony Giddens, Jalan ketiga, pembaharuan demokrasi sosial, ( Jakarta: Gramedia, 1998) .

Hanna Djumhana B, Integrasi Psikologi Dengan Islam,(Yogyakarta: pustaka pelajar, 1995).

Khairuddin Nasution, Islam Tentang Relasi Suami \& Istri (Hukum Perkawinan), (Yogya: Akademia \& Tazzafa, 2004).

Sayyid Sabiq, Fiqh Sunnah 7 (Bandung: AlMa'arif, 1981). 